\title{
A Study on Myogenesis by Regulation of Reactive Oxygen Species and Cytotoxic Activity by Selenium Nanoparticles
}

\author{
Sang-Cheol Lee ${ }^{1,2,3,+}$, Na-Hyun Lee ${ }^{1,3,+} \mathbb{D}$, Kapil D. Patel ${ }^{1,4,+}$, Soo-Kyung Jun ${ }^{5}$, Jeong-Hui Park ${ }^{1}$, \\ Jonathan Campbell Knowles ${ }^{1,6,7}$ (D), Hae-Won Kim 1,2,3,6,8,9,10, Hae-Hyoung Lee 1,2,3,6,*(D) \\ and Jung-Hwan Lee $1,2,3,6,8,9,10, *$ (D)
}

Citation: Lee, S.-C.; Lee, N.-H.; Patel, K.D.; Jun, S.-K.; Park, J.-H.; Knowles, J.C.; Kim, H.-W.; Lee, H.-H.; Lee, J.-H. A Study on Myogenesis by Regulation of Reactive Oxygen Species and Cytotoxic Activity by Selenium Nanoparticles. Antioxidants 2021, 10, 1727. https://doi.org/ $10.3390 /$ antiox 10111727

\section{Academic Editors:}

Alessandra Napolitano and Stanley Omaye

Received: 14 September 2021 Accepted: 27 October 2021 Published: 29 October 2021

Publisher's Note: MDPI stays neutral with regard to jurisdictional claims in published maps and institutional affiliations.

Copyright: (c) 2021 by the authors Licensee MDPI, Basel, Switzerland. This article is an open access article distributed under the terms and conditions of the Creative Commons Attribution (CC BY) license (https:/ / creativecommons.org/licenses/by/ $4.0 /)$.
1 Institute of Tissue Regeneration Engineering (ITREN), Dankook University, 119 Dandae-ro, Cheonan 31116, Chungcheongnam-do, Korea; 72210656@dankook.ac.kr (S.-C.L.); nhlee0609@dankook.ac.kr (N.-H.L.); dynamic2020@korea.ac.kr (K.D.P.); shurins@naver.com (J.-H.P.); j.knowles@ucl.ac.uk (J.C.K.); kimhw@dku.edu (H.-W.K.)

2 Department of Biomaterials Science, College of Dentistry, Dankook University, 119 Dandae-ro, Cheonan 31116, Chungcheongnam-do, Korea

3 Department of Nanobiomedical Science \& BK21 PLUS NBM Global Research Center for Regenerative Medicine, Dankook University, 119 Dandae-ro, Cheonan 31116, Chungcheongnam-do, Korea

4 Department of Materials Science and Engineering, Korea University, Seoul 02841, Korea

5 Department of Dental Hygiene, Hanseo University, Seosan 31962, Korea; iris979@hanseo.ac.kr

6 UCL Eastman-Korea Dental Medicine Innovation Centre, Dankook University, 119 Dandae-ro, Cheonan 31116, Chungcheongnam-do, Korea

7 Division of Biomaterials and Tissue Engineering, Eastman Dental Institute, University College London, London WC1E 6HH, UK

8 Cell \& Matter Institute, Dankook University, Cheonan 31116, Chungcheongnam-do, Korea

9 Department of Regenerative Dental Medicine, College of Dentistry, Dankook University, Cheonan 31116, Chungcheongnam-do, Korea

10 Mechanobiology Dental Medicine Research Center, Cheonan 31116, Chungcheongnam-do, Korea

* Correspondence: haelee@dku.edu (H.-H.L.); ducious@gmail.com (J.-H.L.); Tel.: +82-41-550-3083 (H.-H.L.); +82-41-550-3081 (J.-H.L.); Fax: +82-41-559-7839 (H.-H.L. \& J.-H.L.)

$+\quad$ These authors contributed equally to this work as first authors.

Abstract: Reactive oxygen species (ROS) are continuously produced by skeletal muscle during contractile activity and even at rest. However, the ROS generated from excessive exercise or traumatic damage may produce more ROS than can be neutralized by an antioxidant capacity, which can be harmful to muscle function. In particular, selenium is a known antioxidant that regulates physiological functions such as cell differentiation and anti-inflammatory function. In this study, we developed nano-sized antioxidative biomaterials using selenium to investigate the protective and differentiation effects against $\mathrm{C} 2 \mathrm{C} 12$ myoblasts in an $\mathrm{H}_{2} \mathrm{O}_{2}$-induced oxidative stress environment. The selenium nanoparticles (SeNPs) were produced with a size of $35.6 \pm 4.3 \mathrm{~nm}$ and showed antioxidant effects according to the 3,3',5,5'-tetramethylbenzidine assay. Then, SeNPs were treated to C2C12 cells with or without $\mathrm{H}_{2} \mathrm{O}_{2}$. Our results showed that SeNPs reduced $\mathrm{C} 2 \mathrm{C} 12$ apoptosis and intracellular ROS levels. Additionally, SeNPs effectively up-regulated in the presence of $\mathrm{H}_{2} \mathrm{O}_{2}, M y o D, M y o G, \alpha$-actinin, and myosin heavy chain, which are well known to increase during myoblast differentiation as assayed by qRT-PCR, immunocytochemistry-staining, western blotting. These results demonstrate that SeNPs can accelerate differentiation with its protective effects from the ROS environment and can be applied to the treatment of skeletal muscle in a cellular redox environment.

Keywords: C2C12; skeletal muscle differentiation; selenium nanoparticle; ROS; antioxidant

\section{Introduction}

Skeletal muscle is a highly contractile tissue that makes up a large portion of the total human body mass (40-50\%). Skeletal muscle possesses excellent regenerative capacity upon damage to adapt to various physiological conditions due to their essential role in 
posture and movement [1-4]. Mainly, the resident skeletal muscle stem cells, called satellite cells, control skeletal muscle tissue regeneration. Satellite cells differentiate into myogenic cells and fuse to each other to form a bundle of multinucleated myoblasts, which are mature myofibers [5,6].

During physical activity, skeletal muscle constantly generates reactive oxygen species (ROS) due to their metabolic activity. ROS modulates cellular proliferation, migration, differentiation, and muscle contractions at the physiological level [7,8]. However, prolonged exposure to excessive ROS possibly exceeds the muscle's antioxidant capacity and may result in damage and injury, including irreversible fibrosis and scarring, which can eventually cause loss of muscle function [9]. Unfortunately, no surgical reconstructions or therapeutic interventions allow for complete functional restoration [10]. Thus, the development of therapeutic strategies that treat skeletal injuries is required.

Recently, there have been many reports on the development of biomaterials for tissue regeneration [11-16]. Importantly, biomaterials for tissue-engineered skeletal muscle provide a biophysical microenvironment to help myoblast differentiation and tissue formation [17-19]. In particular, nanoparticles with diameters of 1-100 nm can modulate cell fate by directly delivering themselves to intracellular sites, such as to the cytosol and nucleus [20-22]. Recently, metal (gold, silver, selenium, strontium, copper, and ceria)incorporated nanoparticles showed outstanding biocompatible and antioxidant effects in various areas of tissue regeneration [20,23-27].

Selenium is one of the essential trace elements that regulate various physiological functions, including anti-inflammatory effects and immune functions [28-31], and is also well known to play an essential role in regulating ROS levels [32-35]. Selenium has been reported to protect fibroblasts from oxidative stress [36] and apoptosis [37-41]. Nanoscale selenium is a highly effective molecular compound with higher antioxidant activity and lower toxicity than regular selenium [42]. Therefore, in this study, we focused on the antioxidant effects of SeNPs on skeletal muscle cell differentiation in a ROS exposure environment.

\section{Materials and Methods}

\subsection{Materials}

Sodium selenite $\left(\mathrm{Na}_{2} \mathrm{SeO}_{3}\right.$; Sigma-Aldrich, St. Louis, MO, USA), L-ascorbic acid $\left(\mathrm{C}_{6} \mathrm{H}_{8} \mathrm{O}_{6}\right.$, Sigma, USA), D-(+)-glucose $\left(\mathrm{C}_{6} \mathrm{H}_{12} \mathrm{O}_{6}\right.$, Sigma, USA), sodium hydroxide beads (NaOH, Daejung, Seoul, Korea), and 1N- hydrochloric acid (HCL, Daejung, Korea) were used. All chemicals were reagent-grade and used without further purification.

\subsection{Synthesis of Selenium Nanoparticles (SeNPS)}

SeNPs were synthesized by the reduction method, as previously reported by our group [26]. Briefly, an aqueous solution of sodium selenite $(100 \mathrm{mM})$ was mixed with an aqueous solution of ascorbic acid $(100 \mathrm{mM})$ using magnetic stirring, and the $\mathrm{pH}$ was maintained at 7.1 using $\mathrm{NaOH}(0.1 \mathrm{M})$ or $\mathrm{HCl}(0.1 \mathrm{M})$. The resulting mixture solution color changed from transparent to red and the reaction was carried out for $6 \mathrm{~h}$. Finally, SeNPs were collected by centrifugation at 15,000 rpm for $30 \mathrm{~min}$ and washed with deionized water three times. The final solution was lyophilized to collect the SeNPs.

\subsection{Characterizations of SeNPS}

The morphology and size, crystalline phase, chemical functional groups, surface charge, and optical properties of SeNPs were characterized by transmission electron microscopy (TEM; JEOL-7100, JEOL, Tokyo, Japan), X-ray diffraction (XRD; Rigaku, Tokyo, Japan), Fourier transform infrared spectroscopy (FTIR; Varian 640-IR, CA, USA), zeta potentials (Zetasizer Nano; Malvern Instrument, Worcestershire, UK), and UV-visible analysis (UV-vis, Varian Cary 100, Agilent Technologies, Paolo Alto, CA, USA), respectively. 


\subsection{Peroxidase Activity of SeNPs}

We investigated the oxidase-like activity of SeNPs, as previously reported by our group [26]. Briefly, the catalytic activity (i.e., oxidation of the peroxidase substrate) of SeNPs was observed in 3,3',5,5'-tetramethylbenzidine (TMB) in the presence of hydrogen peroxide $\left(\mathrm{H}_{2} \mathrm{O}_{2}\right.$, Sigma-Aldrich, USA). Two hundred micrograms of SeNPs were dispersed in $200 \mathrm{~mL}$ of $200 \mu \mathrm{g} / \mathrm{mL}$ TMB solution mixed with $\mathrm{H}_{2} \mathrm{O}_{2}$ and placed at room temperature for different times $(0 \mathrm{~h}, 1 \mathrm{~h}$, and $5 \mathrm{~h})$ in the dark, after which optical images were taken. After the predefined reaction time, the supernatant for each sample was collected via centrifugation and the UV-visible absorption $(400-800 \mathrm{~nm})$ range was measured to verify the oxidase-like activity of the SeNPs.

\subsection{Cell Culture}

$\mathrm{C} 2 \mathrm{C} 12$ mouse myoblast cells were maintained at $37^{\circ} \mathrm{C}$ in a $5 \% \mathrm{CO}_{2}$ atmosphere in Dulbecco's modified Eagle's medium (DMEM, Welgene, Dalseogu, Daegu, Korea). Unless otherwise specified, the medium contained $10 \%$ heat-inactivated fetal bovine serum (FBS, Corning, Woodland, CA, USA), $100 \mathrm{U} / \mathrm{mL}$ of penicillin, and $100 \mu \mathrm{g} / \mathrm{mL}$ of streptomycin (PS, Gibco, Grand Island, NY, USA).

Cell medium was changed every two days. When $\mathrm{C} 2 \mathrm{C} 12$ cells reached $70 \%$ confluence, they were detached by treatment with $0.25 \%$ trypsin EDTA (Gibco, Grand Island, NY, USA) and replated for experiments. The cells used in all experiments were between 8 and 10 passages. For myogenic differentiation, cells were seeded at a density of $4 \times 10^{4}$ in 24-well plates. After $24 \mathrm{~h}$ of seeding, cells were treated with media containing SeNPs and then $\mathrm{H}_{2} \mathrm{O}_{2}$ was added to cells after $30 \mathrm{~min}$. Cell culture media were replaced $24 \mathrm{~h}$ later with myogenic differentiation media consisting of DMEM with 1\% PS and 2\% horse serum (Gibco, Grand Island, NY, USA).

\subsection{Cell Viability}

In vitro cell viability on the SeNPs or $\mathrm{H}_{2} \mathrm{O}_{2}$ was studied. $\mathrm{C} 2 \mathrm{C} 12$ cells were seeded into a 96-well plate at $5 \times 10^{3}$ cells per well. After $24 \mathrm{~h}$, either SeNPs $(0-320 \mu \mathrm{g} / \mathrm{mL})$ or $\mathrm{H}_{2} \mathrm{O}_{2}$ $(0-1000 \mu \mathrm{M})$ was treated for 1 day. Then, the cell viability assay was performed using a cell counting kit-8 (CCK-8, Dojindo, Kumamoto, Japan). Briefly, the culture medium containing $10 \%$ CCK-8 solution was replaced in each well of the plate, followed by incubation for $2 \mathrm{~h}$ at $37^{\circ} \mathrm{C}$. After that, the absorbance of each well was read at $450 \mathrm{~nm}$ using a microplate reader (Thermo Fisher Varioskan LUX, Waltham, MA, USA). Cell survival was also examined by live/dead-staining $(0.5 \mu \mathrm{M}$ of calcein $\mathrm{AM}$ and $2 \mu \mathrm{M}$ of ethidium homodimer- 1 solutions, Thermo Fisher, Waltham, MA, USA) and images were taken using an optical microscope (IX71, Olympus, Tokyo, Japan). After staining, the rate of live cells (\%) was quantified using ImageJ software (Bethesda, Maryland, USA).

To examine the cellular cytotoxicity under both SeNPs and $\mathrm{H}_{2} \mathrm{O}_{2}, \mathrm{C} 2 \mathrm{C} 12$ cells were plated in a 96-well plate at a seeding density of $5 \times 10^{3}$ cells. Then, SeNPs $(0-80 \mu \mathrm{g} / \mathrm{mL})$ were treated to cells with or without $\mathrm{H}_{2} \mathrm{O}_{2}(100$ or $200 \mu \mathrm{M})$ for 1 day. The cell viability assay and live/dead-staining were performed as we described above.

\subsection{ROS-Staining}

High oxidative stress conditions were enabled by pretreatment with $500 \mu \mathrm{M}$ of $\mathrm{H}_{2} \mathrm{O}_{2}$ for $4 \mathrm{~h}$ as previously reported by our group [26]. ROS levels were analyzed using the ImageiT LIVE Green Reactive Oxygen Species Detection Kit (Invitrogen, Carlsbad, CA, USA). The cells were gently washed twice with HBSS/Ca/Mg (Welgene, Dalseogu, Daegu, Korea) and labeled with $25 \mu \mathrm{M}$ of carboxy-H2DCFDA to cover the adherent cells for $30 \mathrm{~min}$ at $37^{\circ} \mathrm{C}$. The labeled cells were gently washed three times and observed using a microscope.

\section{8. $q R T-P C R$}

C2C12 cells were cultured with or without SeNPs and $\mathrm{H}_{2} \mathrm{O}_{2}$ for 5 days. Total RNA was harvested using an RNA preparation kit (Geneall, Songpa-gu, Seoul, Korea) accord- 
ing to the manufacturer's instructions and the RNA concentration was analyzed using a Nanodrop (Thermo Fisher, Waltham, MA, USA). First-strand cDNA was developed using an RNA reverse transcription (RT) kit (Bioneer, Daeduk-gu, Daejeon, Korea) according to the manufacturer's instructions. PCR was performed using target gene expression levels normalized to glyceraldehyde 3-phosphate dehydrogenase (Gapdh) levels. The delta cycle threshold $(\mathrm{Ct})$ method was used to calculate relative levels of expression. The primer sequences were as follows: Myogenic determinant $(M y o D)$ forward 5'-GGA GTG GCA GAA AGT TAA G-3', reverse 5'-ACG GGT CAT CAT AGA AGT C-3'; Myogenin (MyoG) forward 5'-GGA TAT GTC TGT TGC CTT C- $3^{\prime}$, reverse $5^{\prime}$-TGG GTG TTA GCC TTA TGT-3'; Alpha actinin ( $\alpha$-Actinin) forward $5^{\prime}$-GGA CTA CAC TGC CTT CTC- $3^{\prime}$, reverse $5^{\prime}$-CAG CCT ATA CTT CAG CCT TT-3'; and Gapdh forward 5'-GGT TGT CTC CTG CGA CTT CA-3', reverse $5^{\prime}$-TAG GGC CTC TCT TGC TCA GT-3'.

\subsection{Myotube Formation and Immunocytochemistry}

C2C12 cells were seeded into 24-well plates at a density of $4 \times 10^{4}$ cells/well; after $24 \mathrm{~h}$, cells were treated with SeNPs $(5-20 \mu \mathrm{g} / \mathrm{mL})$. After $30 \mathrm{~min}$ of treatment with SeNPs, $\mathrm{H}_{2} \mathrm{O}_{2}$ was added to maintain high oxidative stress conditions and myogenic differentiation medium was added for 5 days to induce myotube formation. The differentiation medium was changed every other day. On the 5 days of differentiation, the cells were washed with PBS (Tech and Innovation, Chuncheon, Korea), fixed with $4 \%$ paraformaldehyde (PFA, Tech-innovation, Gangwon-do, Korea) for $30 \mathrm{~min}$, and permeabilized with $0.2 \%$ Triton X-100 (Sigma-Aldrich, USA) for $10 \mathrm{~min}$. After permeabilization, the cells were blocked with 1\% BSA solution for $30 \mathrm{~min}$, incubated with Myosin heavy chain antibody (MHC: 1:400, Santa Cruz Biotechnology, Inc., Dallas, TX, USA) at $4{ }^{\circ} \mathrm{C}$ overnight, and incubated with secondary antibody (FITC, anti-mouse 1:200; Abcam Inc., Cambridge, UK) at room temperature for $2 \mathrm{~h}$. The multinucleate myotubes were observed using a fluorescence microscope (CELENA, Logos Biosystems, Anyang, Korea).

\subsection{Western Blot}

$\mathrm{C} 2 \mathrm{C} 12$ cells were cultured in differentiation media and treated with SeNPs (5 or $10 \mu \mathrm{g})$ in the presence of $50 \mu \mathrm{M}$ of $\mathrm{H}_{2} \mathrm{O}_{2}$ for 5 days as we described above. Then, it was dissolved in RIPA lysis buffer (ELPIS Biotech, Daejeon, Korea) containing protease inhibitor (Halt ${ }^{\mathrm{TM}}$ Protease and Phosphatase Inhibitor Cocktail $(100 \times)$, Thermo Fisher Scientific, Waltham, MA, USA). The total protein concentration was quantified using a Pierce BCA protein assay kit (Thermo Fisher Scientific, Waltham, MA, USA). An equal amount of total proteins per lane was electrophoresed in polyacrylamide gels and transferred onto polyvinylidene difluoride (PVDF, Bio-Rad Laboratories, Hercules, CA, USA) membranes. The membranes were blocked with $5 \%$ bovine serum albumin (BSA, BD Biosciences, Sparks, MD, USA) in TBS-T solution (Tris-buffered saline- $0.1 \%$ Tween, LPS Solution, Daejeon, Korea) for $1 \mathrm{~h}$ and then incubated with primary antibodies in 5\% $(w / v)$ BSA in TBS-T solution at $4{ }^{\circ} \mathrm{C}$ overnight against MYOD (myoblast determination protein 1:1000, Cell Signaling Technology, Danvers, MA, USA), MYOG (1:1000, Millipore, Billerica, MA, USA), BCL-2 (1:1000, Cell Signaling Technology), BAX (1:1000, Abcam, Cambridge, United Kingdom), or $\beta$-ACTIN (Cell Signaling Technology). After washing with TBS-T, the membranes were further incubated with secondary antibodies at room temperature for $1 \mathrm{~h}$. The signals were detected using a western blot imaging system (ibright FL1500, Invitrogen, Carlsbad, CA, USA) and the band intensity was normalized to $\beta$-ACTIN as well as quantified by ImageJ software (National Institutes of Health, Bethesda, MD, USA).

\subsection{Statistical Analysis}

Statistical significance between groups was evaluated by one-way ANOVA followed by Dunnett's multiple comparisons tests or by two-way ANOVA, followed by Dunnett's multiple comparisons tests. GraphPad Prism 8 software (San Diego, CA, USA) was used. 


\section{Results and Discussion}

\subsection{Characterization of SeNPs}

Characteristics0 of SeNPs were investigated to check as-designed size, shape, and chemical composition. The HR-TEM image of SeNPs is shown in Figure 1a. The SeNPs were spherical, with a size of $35.6 \pm 4.3 \mathrm{~nm}$. Next, we investigated the crystal phage structure of the SeNPs. The XRD patterns of SeNPs are shown in Figure $1 \mathrm{~b}$ and they exhibited two broad peaks at $2 \theta=20-30^{\circ}$ and $45-55^{\circ}$, demonstrating a combination of crystalline and amorphous phases of the nanoparticles [43]. The FTIR spectra of the SeNPs are presented in Figure 1c. The sharp and intense peak at $2916.36 \mathrm{~cm}^{-1}$ corresponds to the $-\mathrm{CH}$ group, the peak at $1587.62 \mathrm{~cm}^{-1}$ corresponds to the $-\mathrm{COO}$ group, and the peaks at 1107.29 and $548.55 \mathrm{~cm}^{-1}$ correspond to the $-\mathrm{CO}$ and Se-O groups [44,45]. The obtained FTIR spectra were similarly detected in other selenium particles [26]. The surface charge of the SeNPs was analyzed by zeta potential, confirming that SeNPs are negatively charged, as shown in Figure 1d. The surface charge of the SeNPs was $-13.9 \mathrm{mV}$, which is mainly due to the presence of $-\mathrm{COO},-\mathrm{CO}$, and $-\mathrm{OH}$ chemical groups on the surface, as confirmed by FTIR assessment. It is worthy to note that higher zeta potential was suitable for stable particle colloidal suspensions. Finally, the optical properties of the SeNPs were analyzed by UV-visible spectroscopy. The absorption spectra of the SeNPs are presented in Figure 1e. The SeNPs exhibited a broad absorption peak at $325.24 \mathrm{~nm}$.

\subsection{TMB-Based Oxidase-like Activity}

Antioxidant effect without any supplement is a unique property of selenium-contained particles $[26,46,47]$. Thus, for investigating antioxidant effect of SeNPs, TMB-based oxidaselike activity was performed. Figure $1 \mathrm{f}$ shows optical images of TMB and SeNPs, with a concentration of $200 \mu \mathrm{g} / \mathrm{mL}$ for both and a typical blue color after $1 \mathrm{~h}$ and $5 \mathrm{~h}$ of reaction was noticed. The change in color of SeNPs in TMB solution to blue in the presence of $\mathrm{H}_{2} \mathrm{O}_{2}$ confirms the oxidase-like activity of the SeNPs. Initially (i.e., $\mathrm{t}=0$ ), no color was observed, while over time, the blue color $(t=2 \mathrm{~h})$ became deep blue $(t=5)$, indicating the time-dependent oxidase-like activity of SeNPs. Quantitative analysis of the oxidase-like activity was measured by UV-visible spectroscopy and an absorbance peak was observed at $652 \mathrm{~nm}$. This peak appeared due to the oxidization of TMB. Figure $1 \mathrm{f}$ shows the UV-visible spectra for TMB $(t=0)$ and SeNPs with varying time $(t=0 h, 1 \mathrm{~h}$, and $5 \mathrm{~h})$. The UV-visible absorption value (i.e., the intensity of peak) increased with the reaction time, confirming the intrinsic oxidase-like activity of SeNPs. Previously, we showed that the oxidase-like activity of SeNPs increases with increasing nanoparticle concentration at a constant time [26]. Furthermore, an oxidase-like activity commonly increases with reaction time and nanoparticle dose [48]. Overall, our results suggest that $200 \mu \mathrm{g} / \mathrm{mL}$ of SeNPs can achieve effective oxidase activity in $5 \mathrm{~h}$ of reaction.

\subsection{Effect of Selenium Nanoparticles on Cell Viability in C2C12-Induced ROS Conditions}

Thirty-two milligrams of SeNPs were quantified and dissolved in PBS. Then, the selenium stock was made to the highest concentration of $320 \mu \mathrm{g} / \mathrm{mL}$ and used to treat $\mathrm{C} 2 \mathrm{C} 12$ cells, followed by 2 -fold serial dilutions. As a result of treatment with SeNPs, nontoxic $\mathrm{C} 2 \mathrm{C} 12$ cell viability over $100 \%$ was observed at a concentration of $80 \mu \mathrm{g} / \mathrm{mL}$ or less (Figure 2a,b,e). All data was normalized by control cell numbers. Thus, up to $80 \mu \mathrm{g} / \mathrm{mL}$ was chosen for the next in vitro experiment. In the case of $\mathrm{C} 2 \mathrm{C} 12$ cells treated with hydrogen peroxide to mimic the high-ROS condition, cells survived less in all $\mathrm{H}_{2} \mathrm{O}_{2}$ concentrations from $100 \mu \mathrm{M}$ (Figure 2c,d,f). To observe the SeNPs' cell salvage effect as antioxidant, SeNPs and 100-200 $\mu \mathrm{M}$ of $\mathrm{H}_{2} \mathrm{O}_{2}$ were co-treated (Figure 3). SeNPs could increase cell viability at $10 \mu \mathrm{g} / \mathrm{mL}$ from both 100 and $200 \mu \mathrm{M}$ of $\mathrm{H}_{2} \mathrm{O}_{2}$ challenge conditions, eliciting the protective role against muscle progenitor cells along with other cell types [26,49]. In addition, $20 \mu \mathrm{g} / \mathrm{mL}$ of SeNPs revealed a high average value in cell viability compared to the non-SeNPs-treated condition without statistic difference under $\mathrm{H}_{2} \mathrm{O}_{2}$ challenge conditions, while higher concentrations showed similar cell viability. Since long-term 
SeNPs treatment during differentiation might affect cell viability, the highest concentration was set to $20 \mu \mathrm{g} / \mathrm{mL}$ for further studies, including the differentiation study, and this amount was similarly used in other literature [50].

(a)

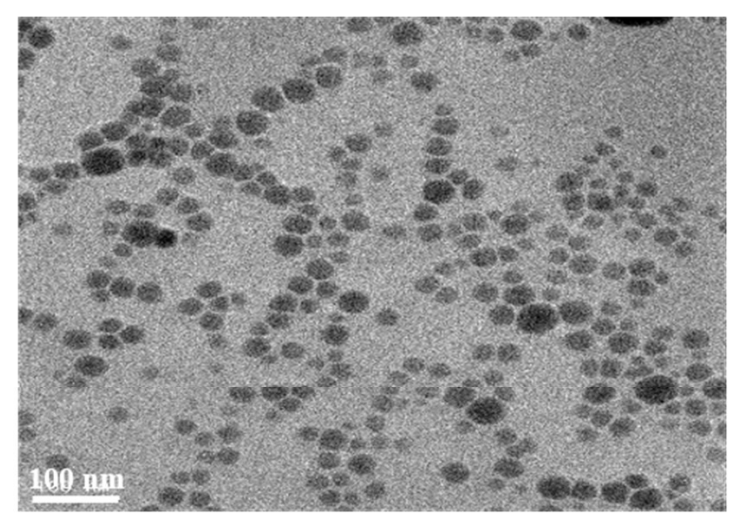

(c)

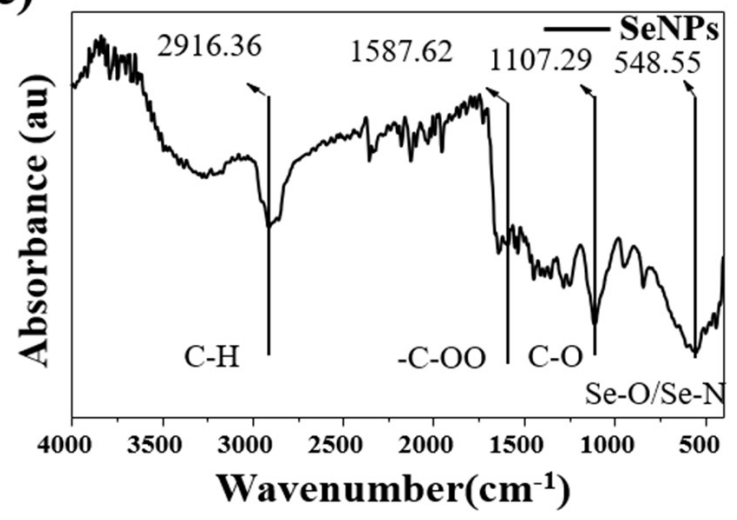

(e)

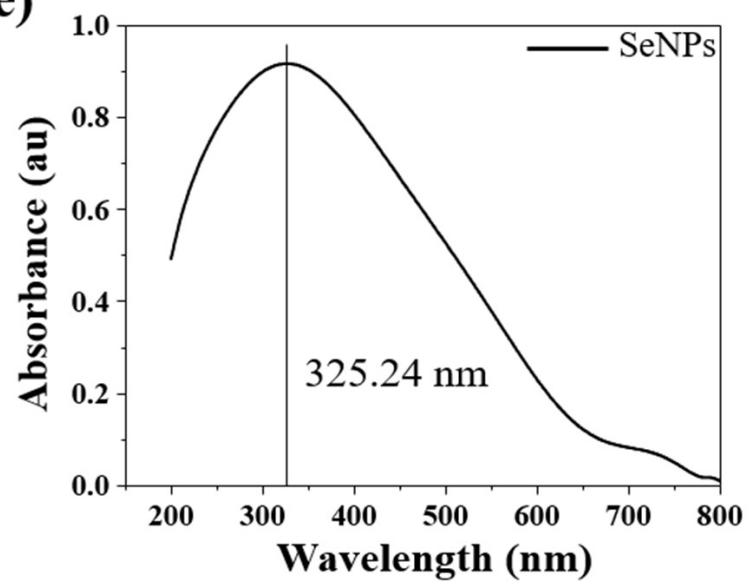

(b)

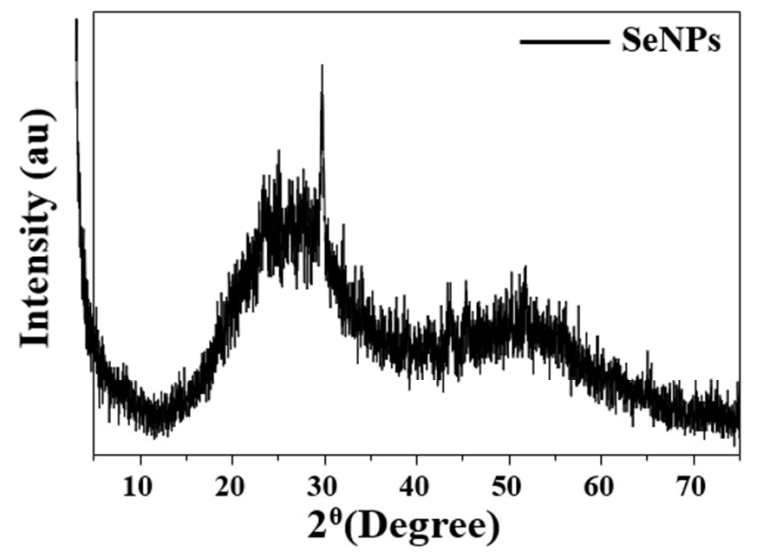

(d)

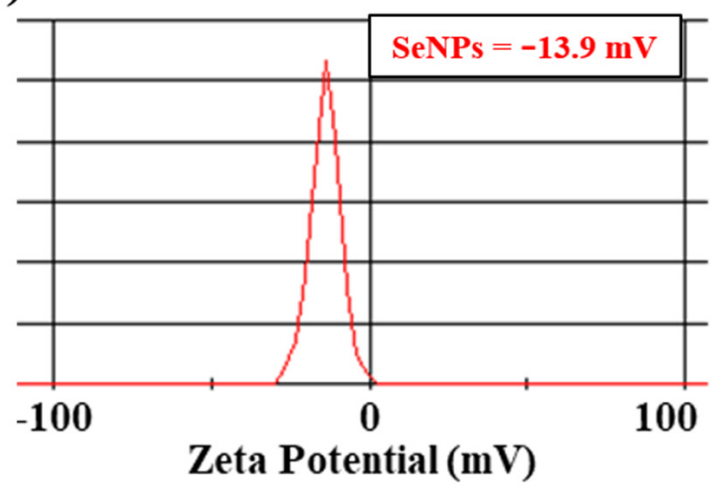

(f)

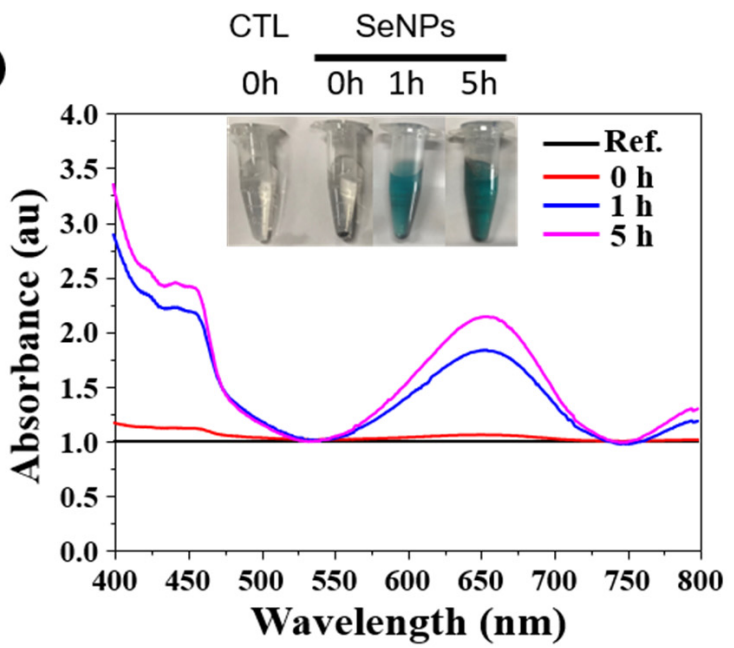

Figure 1. Characterizations of SeNPs. (a) TEM image of SeNPs, (b) XRD patterns, (c) FT-IR spectra of SeNPs, (d) $\zeta$-potentials of SeNPs, and (e) UV-visible spectra of SeNPs in DW. (f) Optical image of the SeNPs reaction with TMB at $0 \mathrm{~h}, 1 \mathrm{~h}$, and $5 \mathrm{~h}$; the corresponding change in color (SeNPs concentration in $200 \mu \mathrm{g} / \mathrm{mL}$ and TMB concentration in $200 \mu \mathrm{g} / \mathrm{mL}$ ) at $\mathrm{pH} 4.0 \mathrm{in}$ DW; and UV-visible absorption spectra of TMB (before reaction as a reference) and after reaction for $0 \mathrm{~h}, 1 \mathrm{~h}$, and $5 \mathrm{~h}$ with and without SeNPs. 
(a)

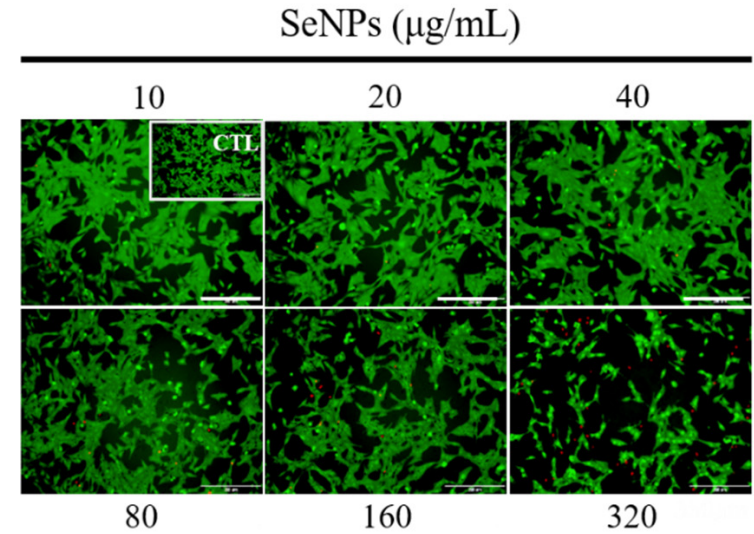

(c)

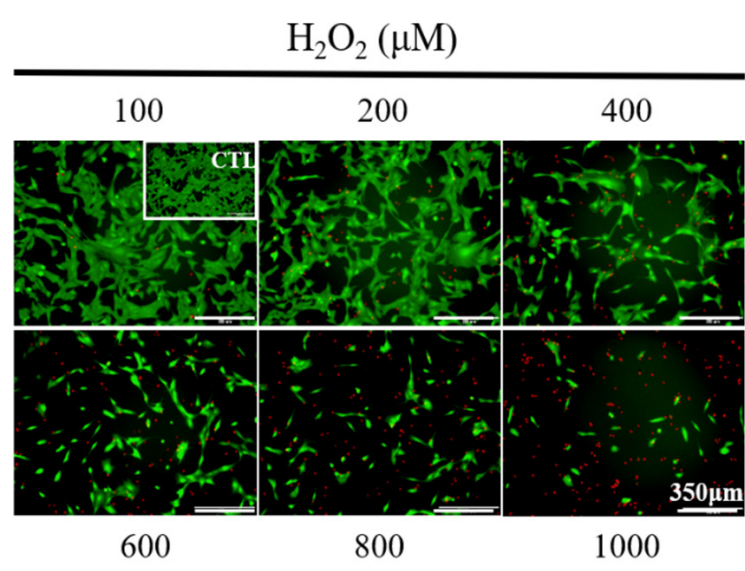

(e)

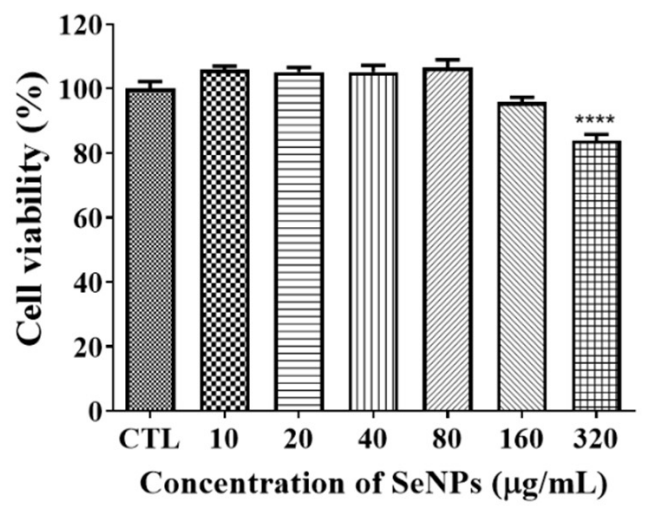

(b)

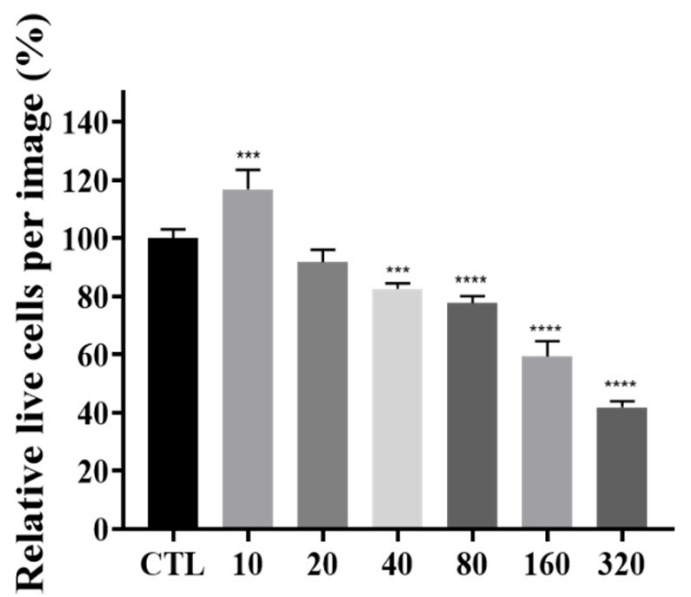

Concentration of SeNPs $(\mu \mathrm{g} / \mathrm{mL})$

(d)

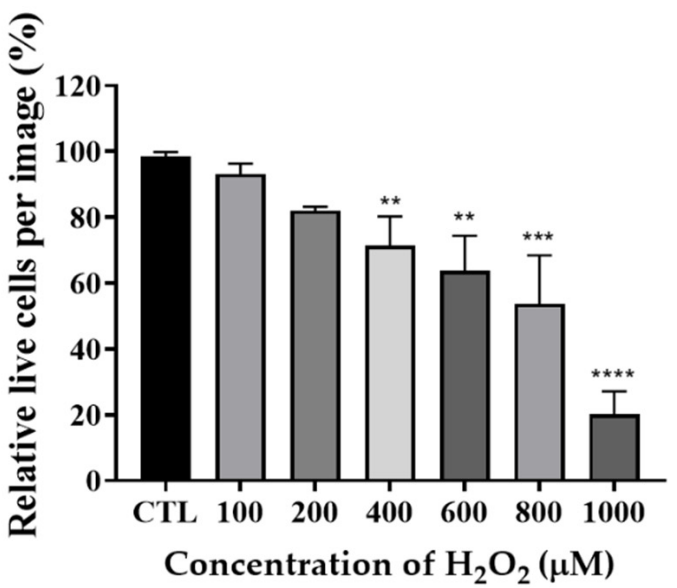

(f)

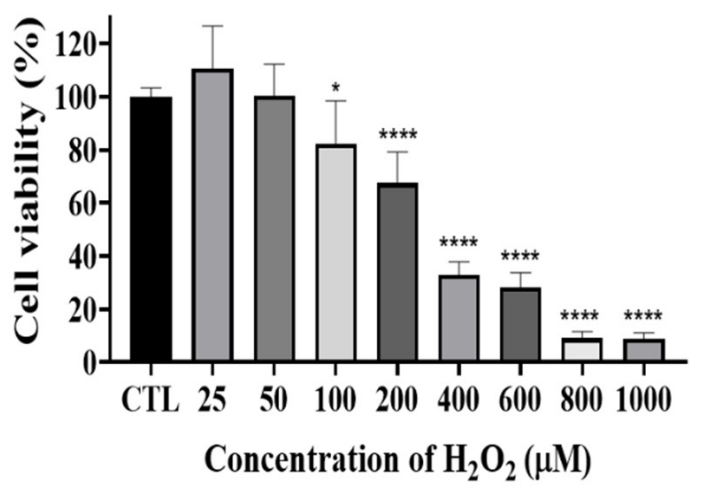

Figure 2. Cell viability was determined by live (green) and dead (red)-staining, and CCK-8 assays. After cell seeding for $24 \mathrm{~h}, \mathrm{C} 2 \mathrm{C} 12$ cells were analyzed using CCK-8 solution and stained using live/dead solution to evaluate viability. (a) Live/dead-staining following treatment with various SeNPs concentrations. (b) The quantitative live/dead assay results, which were treated with SeNPs. (c) Live/dead-staining following treatment with various $\mathrm{H}_{2} \mathrm{O}_{2}$ concentrations. (d) The quantitative live/dead assay results, which were treated with $\mathrm{H}_{2} \mathrm{O}_{2}$. (e) The relative cell viability of $\mathrm{C} 2 \mathrm{C} 12$ cells cultured in different SeNPs concentrations. (f) Viability of $\mathrm{C} 2 \mathrm{C} 12$ cells treated with various concentrations of $\mathrm{H}_{2} \mathrm{O}_{2}$. All data was normalized by control cell numbers. The statistical significance of $(\mathbf{e}, \mathbf{f})$ was calculated using one-way analysis of variance (ANOVA), followed by a two-sided Dunnett's multiple comparison test compared to the control (CTL; scale bar $=350 \mu \mathrm{m})$. ${ }^{*}$ Represents $p<0.05,{ }^{* *} p<0.01,{ }^{* * *} p<0.001$, and ${ }^{* * * *} p<0.0001 ; n=3 .{ }^{*}$ compared with the SeNPs and $\mathrm{H}_{2} \mathrm{O}_{2}$-untreated groups. 
(a)

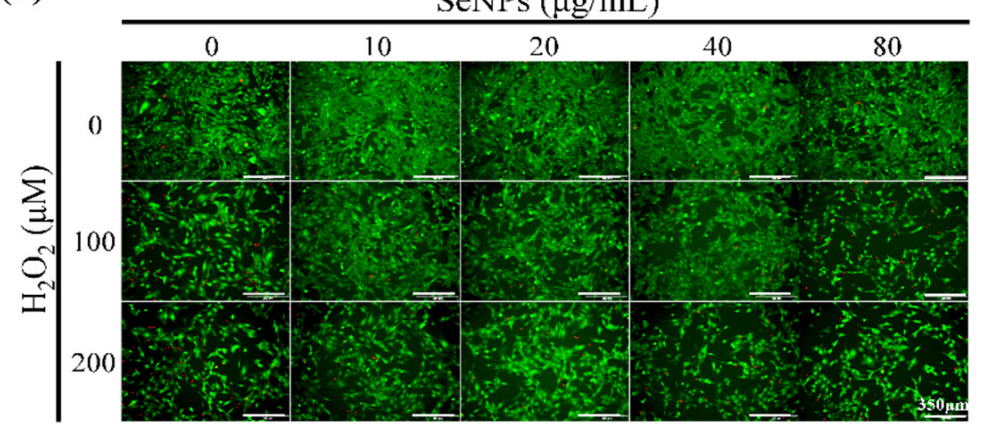

(b)

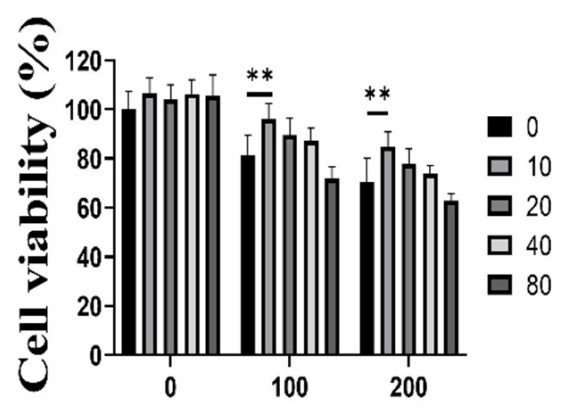

Figure 3. Cell viability was determined by live (green) and dead (red)-staining, and CCK-8 assays. After cell seeding for $24 \mathrm{~h}, \mathrm{C} 2 \mathrm{C} 12$ cells were analyzed using CCK-8 solution and stained using live/dead solution to evaluate viability. (a) Live/dead-staining following treatment with various SeNPs concentrations and $\mathrm{H}_{2} \mathrm{O}_{2}$. (b) Viability of C2C12 cells treated with various concentrations of SeNPs and $\mathrm{H}_{2} \mathrm{O}_{2}$. The statistical significance of (b) was calculated using two-way ANOVA, followed by a two-sided Dunnett's multiple comparison test compared to untreated groups (scale bar $=350 \mu \mathrm{m})$.

** Represents $p<0.01$.

\subsection{ROS-Staining}

As high levels of ROS have been reported to induce apoptosis and inhibit the differentiation of muscle progenitor cells during repair and regeneration [51], ROS-staining was analyzed to confirm the ability of SeNPs to regulate ROS. To measure intracellular ROS production, we used 5-(and-6)-carboxy-29,79-dichlorodihydrofluorescein diacetate (carboxy H2DCFDA) after SeNPs and $500 \mu \mathrm{M}$ of $\mathrm{H}_{2} \mathrm{O}_{2}$ treatment. In total, $500 \mu \mathrm{M}$ of $\mathrm{H}_{2} \mathrm{O}_{2}$ was selected to maximize the ROS production within the limitation of ROS dye sensitivity and to investigate the antioxidant role of SeNPs in a high-ROS environment [26,52]. The ROS production was confirmed at the 4 th hour because it showed toxicity after $24 \mathrm{~h}$. In addition, we wanted to confirm the dramatic cytoprotective and antioxidant effects at high $\mathrm{H}_{2} \mathrm{O}_{2}$ concentrations, such as $500 \mu \mathrm{M}$, and the low intensity of ROS-staining at $200 \mu \mathrm{M}$, confirming cell viability. As shown in Figure 4a, control cells showed a large number of fluorescent cells. In contrast, the cells treated with $5 \mu \mathrm{g} / \mathrm{mL}$ of SeNPs showed weak fluorescence, indicating that $5 \mu \mathrm{g} / \mathrm{mL}$ of SeNPs efficiently controlled ROS. Furthermore, it has been suggested that ROS may affect several cellular activities. Figure $4 \mathrm{~b}$ shows the results obtained by analyzing the intensity and positive areas of staining using ImageJ. As a result of the intensity analysis of fluorescently stained cells, the SeNP-treated group showed a lower intensity than the untreated group and the highest decrease was observed at $5 \mu \mathrm{g} / \mathrm{mL}$ of SeNPs. ROS generated through various extracellular and intracellular actions attract attention as novel signaling mediators involved in the growth, differentiation, progression, and death of cells [53]. Previous studies have shown that another type of stress (heat) possibly causes overproduction and accumulation of ROS, resulting in damage to cells, and SeNPs could protect the apoptosis of C2C12 induced by high ROS [49]. These results, in addition to previous studies revealing the therapeutic role of SeNPs as antioxidants, suggest that SeNPs protect cells by regulating ROS and may be involved in various cellular activities [54,55]. 
(a)

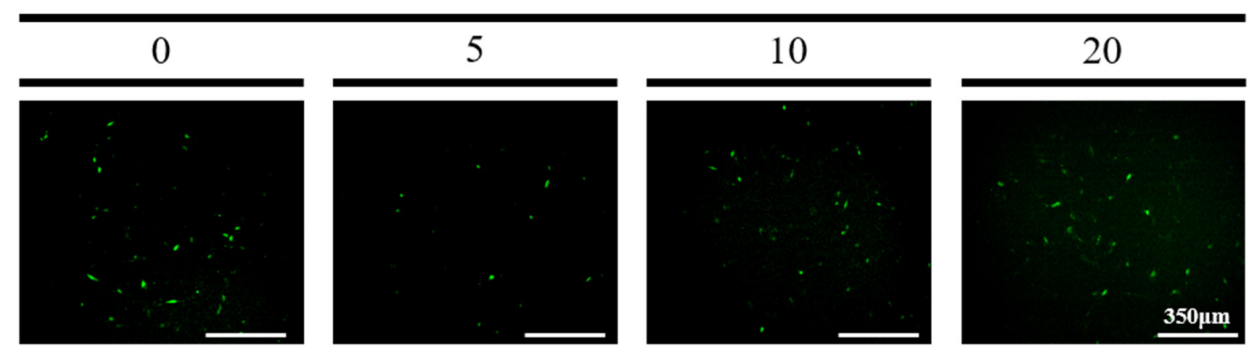

(b)
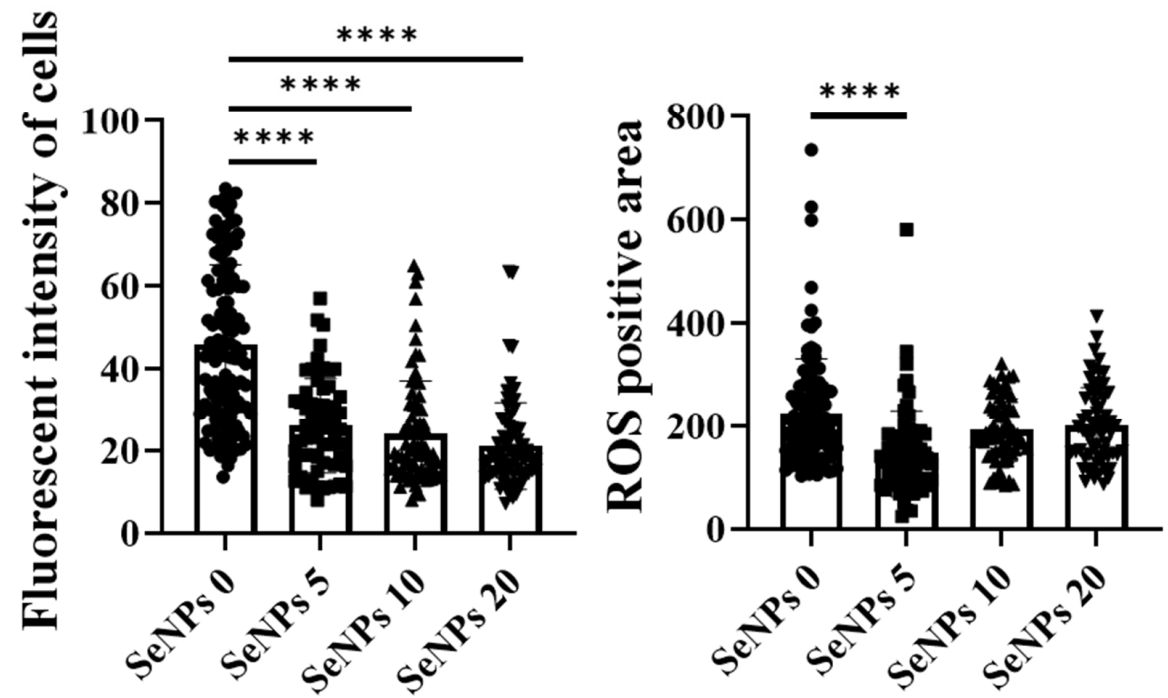

Figure 4. $\mathrm{C} 2 \mathrm{C} 12$ cells were exposed to $500 \mu \mathrm{M}$ of $\mathrm{H}_{2} \mathrm{O}_{2}$ to induce oxidative stress and then were recovered by culturing in a medium with or without SeNPs. High oxidative stress conditions were enabled by pretreatment with $\mathrm{H}_{2} \mathrm{O}_{2}$ for $4 \mathrm{~h}$. (a) SeNP treatment reduced the levels of reactive oxygen species (ROS). (b) The fluorescence intensity of cells and ROS-positive areas were measured using ImageJ. Statistical significance was calculated using one-way ANOVA, followed by a two-sided Dunnett post hoc test compared to the untreated SeNPs group (scale bar $=350 \mu \mathrm{m}$ ). ${ }^{* * *}$ Represents $p<0.0001 ; n=5$.

\subsection{Effect of Selenium Nanoparticles on the Expression of Myogenic Genes Determined by $q R T-P C R$}

To confirm the effect of SeNPs, qRT-PCR was used to investigate the myogenicrelative mRNA expression levels such as $M y o D$, one of the earliest markers of myogenesis; MyoG, known as a transcription factor for myoblast differentiation; and $\alpha$-Actinin, which is involved in the assembly and maintenance of muscle fibers. Figure 5 shows that SeNPs effectively up-regulated myogenic-relative genes after 5 days of culture in differentiation media with or without $\mathrm{H}_{2} \mathrm{O}_{2}$. In the absence of $\mathrm{H}_{2} \mathrm{O}_{2}$, the expression of the $M y o D$ gene did not show any significant differences. The expression of the $M y o G$ gene was $1.32 \pm 0.1-1.60 \pm 0.04$ in all SeNP-treated groups and $\alpha$-Actinin gene expression increased to $1.61 \pm 0.1$ and $1.35 \pm 0.04$ when the cells were treated with $5-10 \mu \mathrm{g} / \mathrm{mL}$ of SeNPs. Under $\mathrm{H}_{2} \mathrm{O}_{2}$ conditions, the expression of the $M y o D$ gene increased to $1.77 \pm 0.29$ and $2.39 \pm 0.25$ when treated with $5-10 \mu \mathrm{g} / \mathrm{mL}$ of SeNPs. The expression of the MyoG gene was $1.73 \pm 0.06$ in the group treated with $10 \mu \mathrm{g} / \mathrm{mL}$ of SeNPs and the $\alpha$-Actinin gene increased to $1.39 \pm 0.08 \sim 1.78 \pm 0.1$ in all groups treated with SeNPs. In addition to the previous study which found that antioxidant ascorbic acid $(200 \mu \mathrm{M})$ can promote the differentiation of C2C12 cells, it was confirmed that SeNPs $(5-20 \mu \mathrm{g} / \mathrm{mL})$ could also be effective in differentiation promotion in C2C12 cells [56]. Along with the therapeutic result of 
seleno-proteins to myogenic cells challenged with heat stress-induced high ROS, in which $M y o D$ and $M y o G$ were upregulated in the presence of selenoproteins [57], it was confirmed that not only heat stress but also ROS could be modulated to influence differentiation.
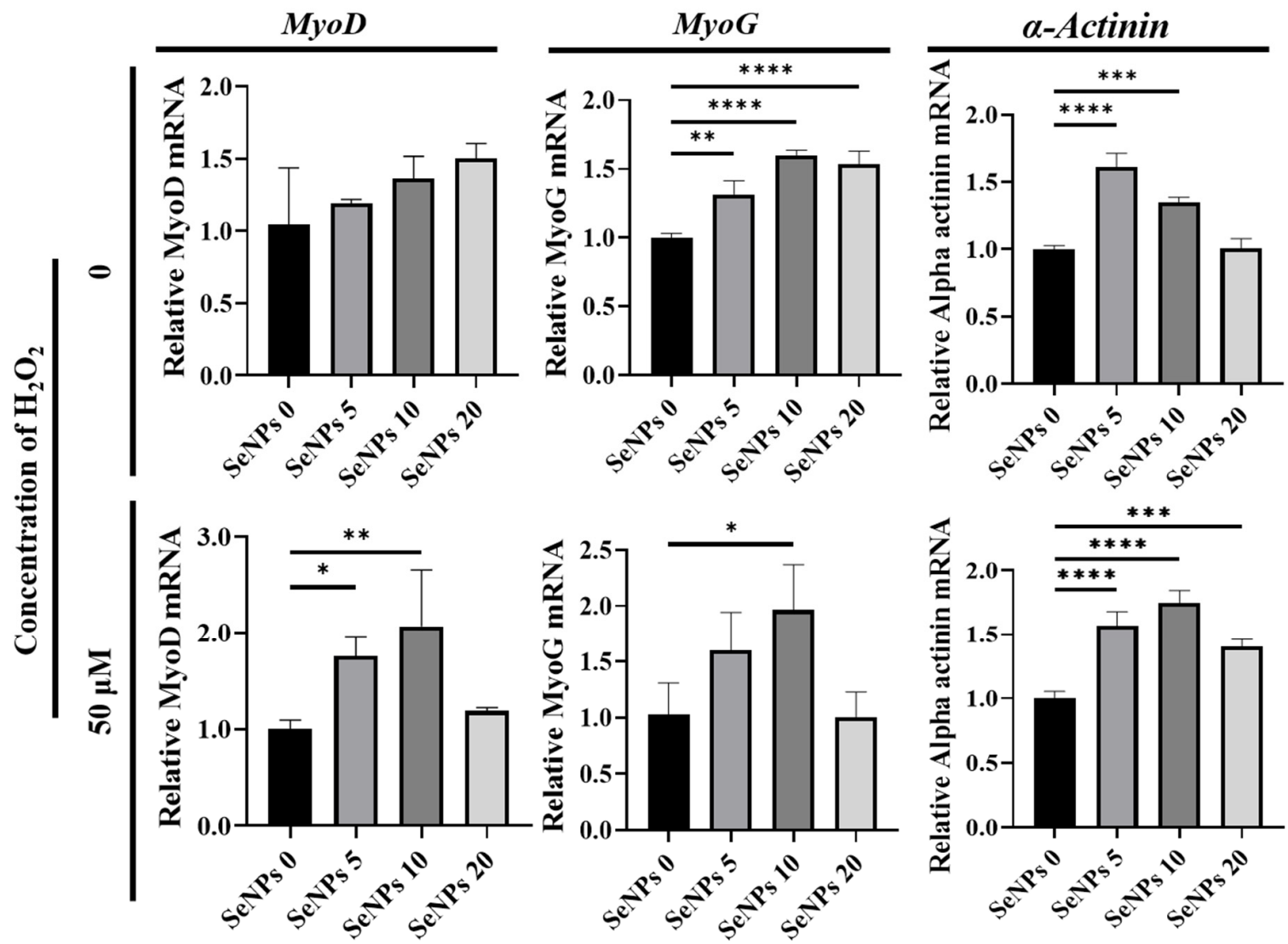

Figure 5. The effect of SeNPs on the expression of myogenic genes through qRT-PCR analysis. The relative expression levels of target genes normalized to Gapdh were calculated using the delta cycle threshold (Ct) method. The figure shows the relative expression of multiple genes relative to gene expression in the negative control treatment cells. The results of the qRT-PCR analysis of myogenic markers five days after treatment with myogenic differentiation media. In the group treated with selenium, the activities of $M y o D, M y o G$, and $\alpha$-actinin were higher than those in the group not treated with selenium. Statistical significance was calculated using one-way ANOVA, followed by a two-sided Dunnett post hoc test compared to the untreated SeNPs group ${ }^{*}$ Represents $p<0.05$, ${ }^{* *} p<0.01$, ${ }^{* *} p<0.001$, and ${ }^{* * *} p<0.0001 ; n=3$.

\subsection{Effect of Selenium Nanoparticles on Myotube Formation}

To evaluate whether SeNPs are effective in the differentiation of $\mathrm{C} 2 \mathrm{C} 12$ cells, immunocytochemistry (ICC)-staining was performed on the 5th day after replacement with myogenic differentiation media (Figure 6a). To quantify the degree of differentiation, the myotube fusion index was calculated by the proportion of nuclei in myotubes to the total nuclei. To quantify and analyze the degree of differentiation of $\mathrm{C} 2 \mathrm{C} 12$ cells, the fusion index and area of the myotube were analyzed. First, in the $\mathrm{H}_{2} \mathrm{O}_{2}$ untreated group, the fusion index increased by approximately $14 \%$ in the $5 \mu \mathrm{g} / \mathrm{mL}$ of the SeNPs-treated group compared to the untreated SeNPs group and no significant differences were found in the area. In the $25 \mu \mathrm{M}$ of the $\mathrm{H}_{2} \mathrm{O}_{2}$ treatment group, the fusion index increased by approximately $13-29 \%$ in the SeNPs treatment group and the area increased by approximately 6-9. In the $50 \mu \mathrm{M}$ of the $\mathrm{H}_{2} \mathrm{O}_{2}$ treatment group, the fusion index increased by approximately $14-23 \%$ in the $5-10 \mu \mathrm{g} / \mathrm{mL}$ of the SeNPs treatment group and the area increased by approximately 4-10 (Figure 6b). From these results, we confirmed that the expression of myogenic markers increased upon SeNPs treatment compared to the untreated group and also SeNPs can be involved in myogenesis by regulating ROS even in a ROS environment 
induced by $\mathrm{H}_{2} \mathrm{O}_{2}$. In a previous study, heat stress induced the downregulation of the $\mathrm{C} 2 \mathrm{C} 12$ gene and the seleno-protein had a potential protective effect under heat stress [49]. In addition, we confirmed the potential protective effect against damage to $\mathrm{C} 2 \mathrm{C} 12$ cells and the upregulation of both the gene and protein expression even in the ROS environment.

(a) SeNPs $(\mu \mathrm{g} / \mathrm{mL})$

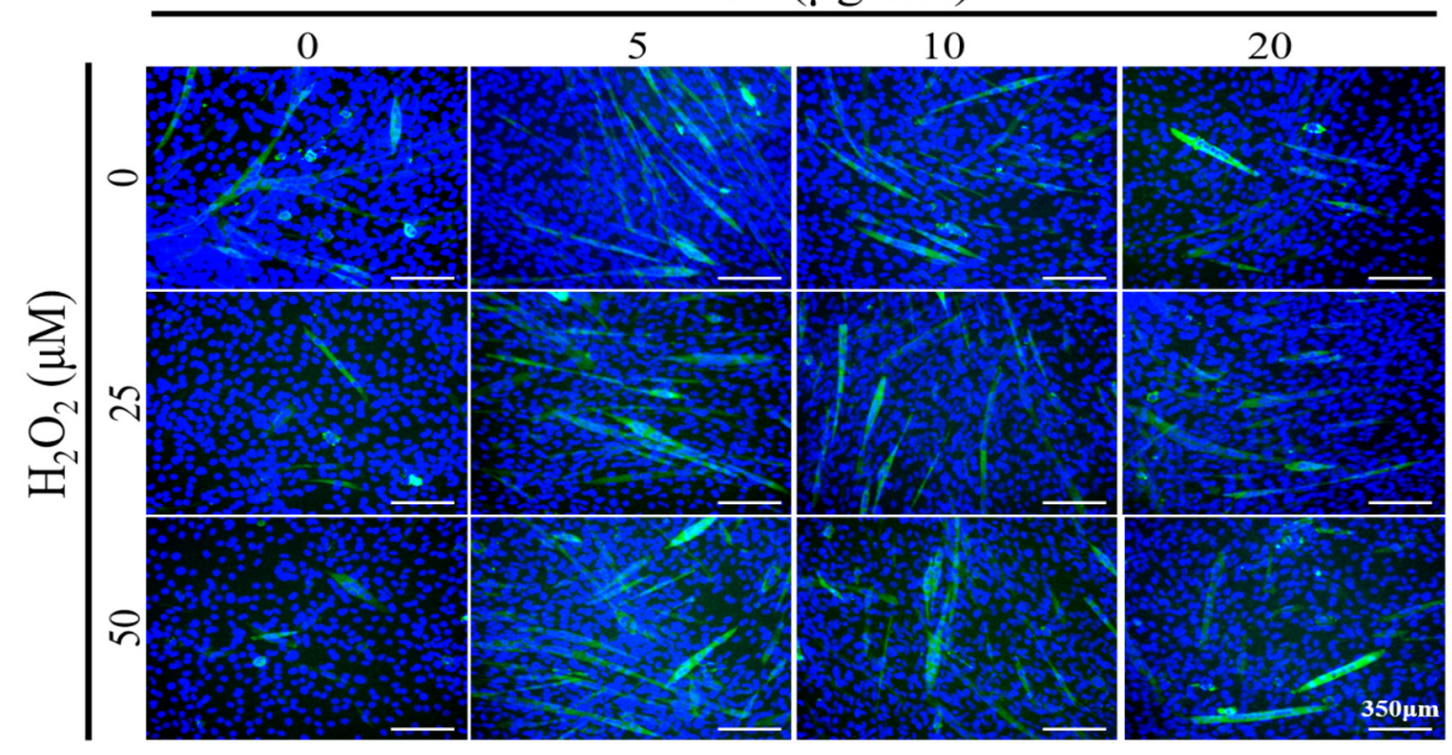

(b)

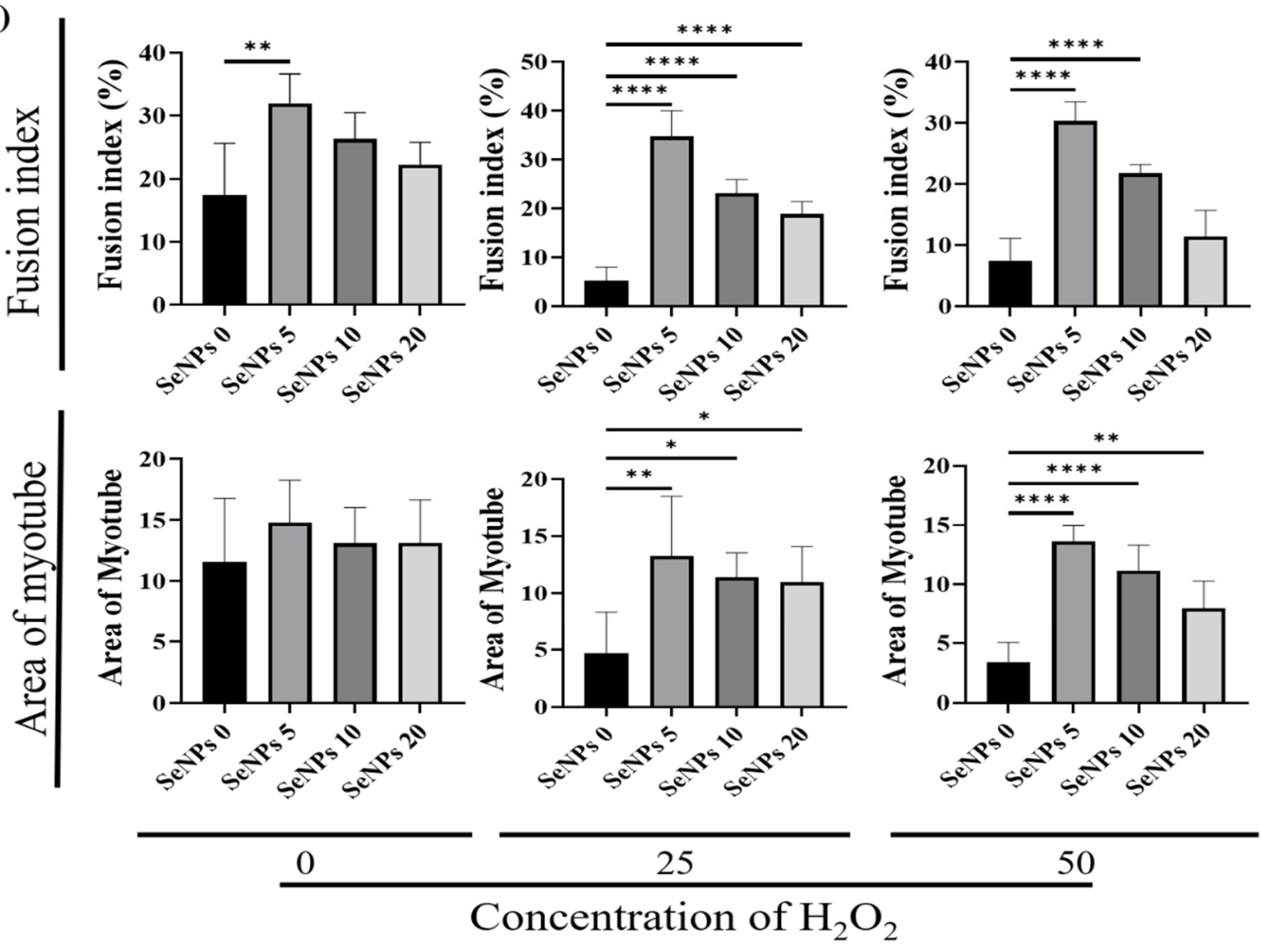

Figure 6. Myogenic differentiation of $\mathrm{C} 2 \mathrm{C} 12$ cells according to SeNPs treatment. (a) Image using MHC after 5 days of differentiation induced by SeNPs treatment. (b) Quantification of myogenic differentiation. Analysis was performed using ImageJ software. Statistical significance was calculated using one-way ANOVA, followed by a two-sided Dunnett post hoc test compared to the untreated SeNPs group * Represents $p<0.05,{ }^{* *} p<0.01$, and ${ }^{* * *} p<0.0001 ; n=3$. 


\subsection{Western Blot}

It was confirmed that SeNPs protect cells from ROS and promote differentiation in the ROS condition. Next, we identified major apoptotic signaling molecules, such as BAX and BCL-2, and major myogenesis signaling molecules, such as MYOD and MYOG, by western blot analysis. This experiment was conducted at a concentration of $5-10 \mu \mathrm{g} / \mathrm{mL}$ of SeNPs, which confirmed a higher level of differentiation through ICC-staining with MHC. In the case of MYOD, the SeNP-treated group showed a significant increase in expression level compared to the untreated group (Figure 7a). However, in the case of MYOG, only the $5 \mu \mathrm{g} / \mathrm{mL}$ of the SeNPs treatment group showed an increase in expression (Figure 7a). Similar to the myogenic effect from another natural antioxidant (curcumin, $1 \mu \mathrm{M}$ ) displaying enhanced MHC (muscle differentiation marker), we observed enhancement of myogenic proteins [58]. In the case of BCL-2, an antiapoptotic factor, a significant increase was confirmed in the $5 \mu \mathrm{g} / \mathrm{mL}$ of the SeNPs treatment group (Figure $7 \mathrm{~b}$ ); in the case of $\mathrm{BAX}$, the $5 \mu \mathrm{g} / \mathrm{mL}$ of the SeNPs treatment group showed similar results to the untreated group (Figure $7 \mathrm{~b}$ ). These data show not only enhanced expression of markers at the RNA level but also enhanced expression at the protein level. In support of previous studies showing that SeNPs play an important role in ROS regulation by analyzing apoptosis signals $[32,35]$, their role in protecting cells from ROS and promoting myoblast differentiation was confirmed.

(a)
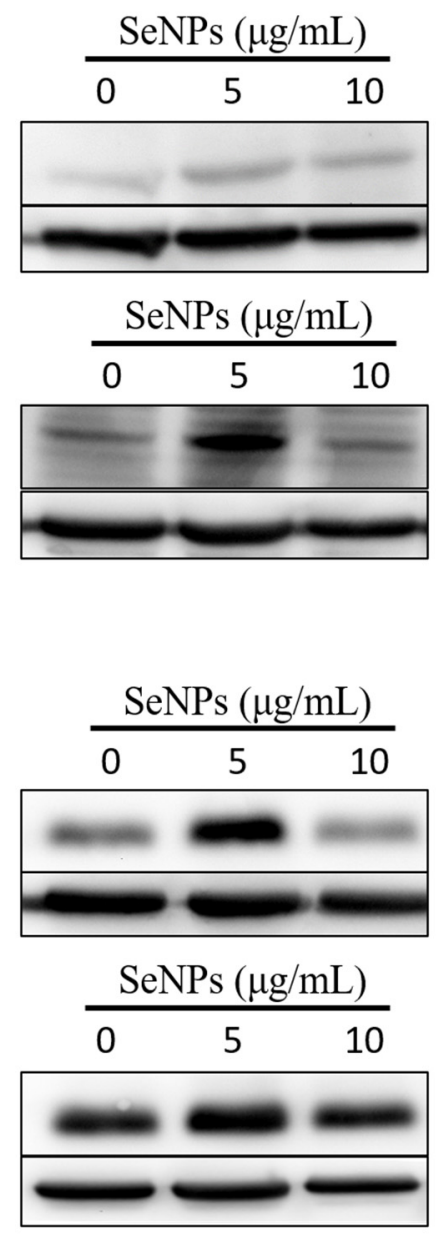
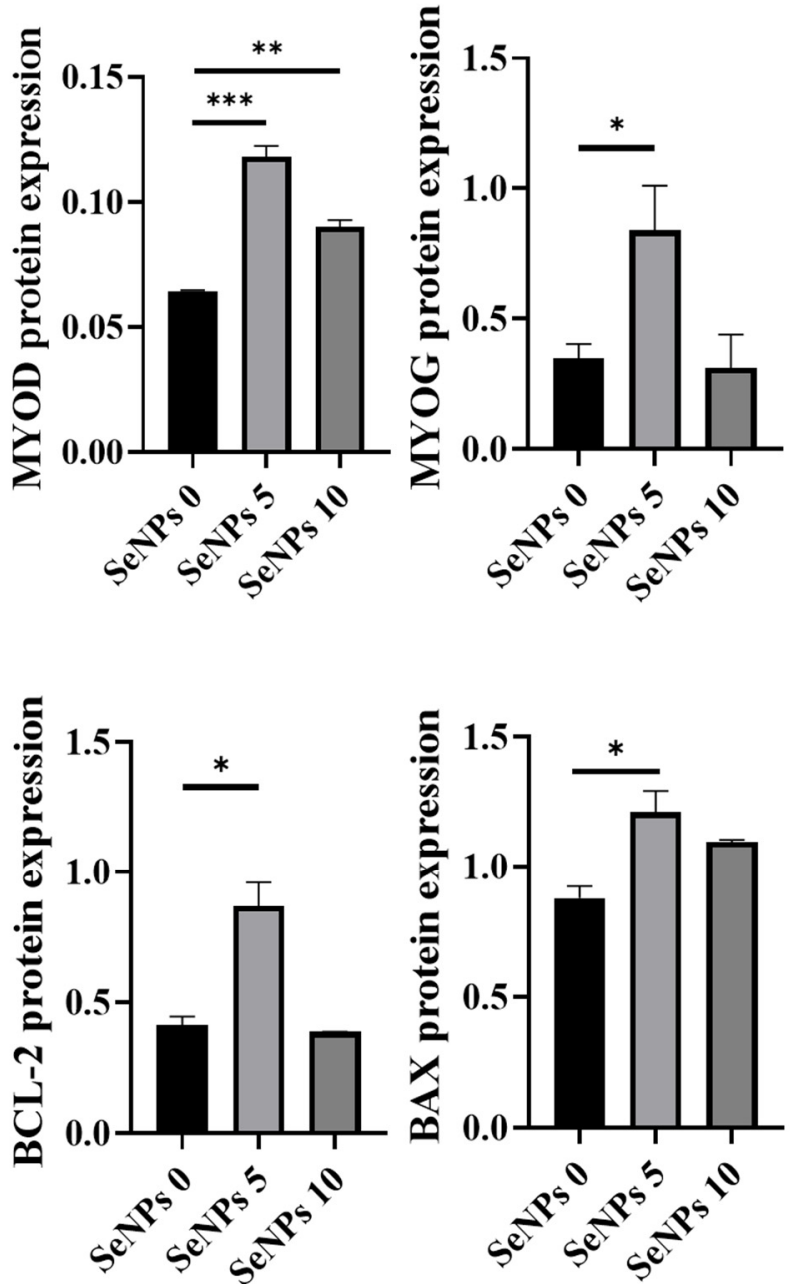

Figure 7. SeNPs upregulate myogenic markers during C2C12 cell differentiation and prevent apoptosis. (a) SeNPs promote myogenic differentiation and (b) increase cell viability by protecting $\mathrm{C} 2 \mathrm{C} 12$ cells under $50 \mu \mathrm{M}$ of $\mathrm{H}_{2} \mathrm{O}_{2}$ for 5 days. Statistical significance was calculated using one-way ANOVA, followed by a two-sided Dunnett post hoc test compared to the untreated SeNPs group. ${ }^{*}$ Represents $p<0.05,{ }^{* *} p<0.01$, and ${ }^{* * *} p<0.001 ; n=3$. 


\section{Conclusions}

The purpose of this study was to investigate the efficiency of apoptosis protection and differentiation promotion through ROS regulation of SeNPs in the ROS environment in $\mathrm{C} 2 \mathrm{C} 12$ cells. The findings of this study are schematically presented in Figure 8, which illustrates a series of antioxidant effects of the SeNPs during the myogenic differentiation. This study revealed that SeNPs effectively restored C2C12 cells from the constant $\mathrm{H}_{2} \mathrm{O}_{2}$ exposure environment via down-regulation of ROS and enhanced myogenic differentiation in both normal and high-ROS conditions. In particular, SeNPs increased myogenic-related mRNA levels ( $M y o D, M y o G$, and $\alpha$-actinin) and promoted multinucleated mature myoblasts. Additionally, SeNPs enhanced the production of the myogenic protein (MYOD and MYOG) and anti-apoptotic protein (BCL-2). Collectively, it can be concluded that SeNPs showed the potential for skeletal muscle repair by acceleration of myogenic differentiation via tuning the ROS production. Along with the ROS regulatory pathway of SeNPs in the myogenic differentiation condition, the clinical effectiveness of SeNPs for muscle tissue regeneration needs to be reinforced in future animal studies.

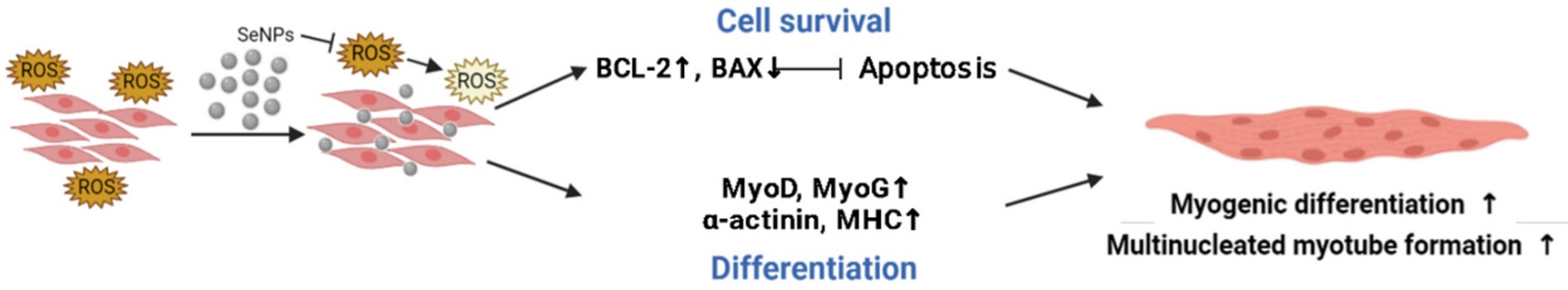

Figure 8. Schematic diagram of $\mathrm{C} 2 \mathrm{C} 12$ cells cultured and treated with SeNPs for myogenic differentiation. SeNPs treatment protects cells from ROS (orange is higher ROS; yellow is lower ROS), thereby increasing cell viability and promoting cell differentiation, contributing to multinucleated myotube formation.

Author Contributions: Conceptualization, S.-C.L., N.-H.L., K.D.P., Jonathan Knowles and J.-H.L.; methodology, J.-H.L.; validation, S.-C.L., N.-H.L. and K.D.P.; formal analysis, S.-C.L., N.-H.L. and K.D.P.; investigation, S.-C.L., N.-H.L. and K.D.P.; resources, S.-K.J., H.-H.L. and J.-H.L.; data curation, S.-C.L., N.-H.L. and K.D.P.; writing—original draft preparation, S.-C.L., N.-H.L. and K.D.P.; writingreview and editing, J.-H.P., J.C.K., H.-W.K., H.-H.L. and J.-H.L.; visualization, S.-C.L. and N.-H.L.; supervision, H.-W.K., H.-H.L. and J.-H.L.; project administration, J.C.K., H.-W.K., H.-H.L. and J.-H.L.; funding acquisition, S.-K.J., H.-W.K., H.-H.L. and J.-H.L. All authors have read and agreed to the published version of the manuscripts.

Funding: This work was supported by a National Research Foundation of Korea (NRF) grant funded by Medical Research Center Program (NRF-2021R1A5A2022318), the Global Research Development Center Program (2018K1A4A3A01064257), Priority Research Center Program provided by the Ministry of Education (2019R1A6A1A11034536), and Young Researcher Program (NRF2019R1C1C1002490 and 2021R1C1C1010005). The present research was also supported by the research fund of Dankook University for the 2019 University Innovation Support Program.

Institutional Review Board Statement: Not applicable.

Informed Consent Statement: Not applicable.

Data Availability Statement: The data presented in this study are available in article.

Conflicts of Interest: The authors declare no conflict of interest. The funders had no role in the design of the study; in the collection, analyses, or interpretation of data; in the writing of the manuscript; or in the decision to publish the results. 


\section{References}

1. Zhang, D.; Yan, K.; Zhou, J.; Xu, T.; Xu, M.; Lin, J.; Bai, J.; Ge, G.; Hu, D.; Si, W.; et al. Myogenic differentiation of human amniotic mesenchymal cells and its tissue repair capacity on volumetric muscle loss. J. Tissue Eng. 2019, 10. [CrossRef]

2. Carleton, M.M.; Sefton, M.V. Promoting endogenous repair of skeletal muscle using regenerative biomaterials. J. Biomed. Mater. Res. Part A 2021, 109, 2720-2739. [CrossRef]

3. Csapo, R.; Gumpenberger, M.; Wessner, B. Skeletal muscle extracellular matrix-what do we know about its composition, regulation, and physiological roles? A narrative review. Front. Physiol. 2020, 11, 253. [CrossRef] [PubMed]

4. Mukund, K.; Subramaniam, S. Skeletal muscle: A review of molecular structure and function, in health and disease. Wiley Interdiscip. Rev. Syst. Biol. Med. 2020, 12, e1462. [CrossRef] [PubMed]

5. Rajasekaran, N.S.; Shelar, S.B.; Jones, D.P.; Hoidal, J.R. Reductive stress impairs myogenic differentiation. Redox Biol. 2020, 34, 101492. [CrossRef]

6. Laumonier, T.; Menetrey, J. Muscle injuries and strategies for improving their repair. J. Exp. Orthop. 2016, 3, 15. [CrossRef]

7. Shan, H.; Gao, X.; Zhang, M.; Huang, M.; Fang, X.; Chen, H.; Tian, B.; Wang, C.; Zhou, C.; Bai, J.; et al. Injectable ROS-scavenging hydrogel with MSCs promoted the regeneration of damaged skeletal muscle. J. Tissue Eng. 2021, 12. [CrossRef]

8. Barbieri, E.; Sestili, P. Reactive oxygen species in skeletal muscle signaling. J. Signal Transduct. 2012, 2012, 982794. [CrossRef]

9. Zhou, T.; Prather, E.R.; Garrison, D.E.; Zuo, L. Interplay between ROS and antioxidants during ischemia-reperfusion injuries in cardiac and skeletal muscle. Int. J. Mol. Sci. 2018, 19, 417. [CrossRef]

10. Liu, J.; Saul, D.; Böker, K.O.; Ernst, J.; Lehman, W.; Schilling, A.F. Current methods for skeletal muscle tissue repair and regeneration. BioMed Res. Int. 2018, 2018, 1984879. [CrossRef]

11. Singh, R.K.; Knowles, J.C.; Kim, H.-W. Advances in nanoparticle development for improved therapeutics delivery: Nanoscale topographical aspect. J. Tissue Eng. 2019, 10. [CrossRef]

12. Qin, D.; Zhang, H.; Zhang, H.; Sun, T.; Zhao, H.; Lee, W.H. Anti-osteoporosis effects of osteoking via reducing reactive oxygen species. J. Ethnopharmacol. 2019, 244, 112045. [CrossRef] [PubMed]

13. Mazzola, L. Commercializing nanotechnology. Nat. Biotechnol. 2003, 21, 1137-1143. [CrossRef] [PubMed]

14. Paull, R.; Wolfe, J.; Hebert, P.; Sinkula, M. Investing in nanotechnology. Nat. Biotechnol. 2003, 21, 1144-1147. [CrossRef]

15. Jo, S.B.; Erdenebileg, U.; Dashnyam, K.; Jin, G.Z.; Cha, J.R.; El-Fiqi, A.; Knowles, J.C.; Patel, K.D.; Lee, H.H.; Lee, J.H.; et al. Nano-graphene oxide/polyurethane nanofibers: Mechanically flexible and myogenic stimulating matrix for skeletal tissue engineering. J. Tissue Eng. 2020, 11. [CrossRef]

16. Wang, Z.; Liu, H.; Luo, W.; Cai, T.; Li, Z.; Liu, Y.; Gao, W.; Wan, Q.; Wang, X.; Wang, J.; et al. Regeneration of skeletal system with genipin crosslinked biomaterials. J. Tissue Eng. 2020, 11. [CrossRef]

17. Wolf, M.T.; Daly, K.A.; Reing, J.E.; Badylak, S.F. Biologic scaffold composed of skeletal muscle extracellular matrix. Biomaterials 2012, 33, 2916-2925. [CrossRef] [PubMed]

18. Corona, B.T.; Ward, C.L.; Baker, H.B.; Walters, T.J.; Christ, G.J. Implantation of in vitro tissue engineered muscle repair constructs and bladder acellular matrices partially restore in vivo skeletal muscle function in a rat model of volumetric muscle loss injury. Tissue Eng. Part A 2014, 20, 705-715. [CrossRef]

19. Perniconi, B.; Costa, A.; Aulino, P.; Teodori, L.; Adamo, S.; Coletti, D. The pro-myogenic environment provided by whole organ scale acellular scaffolds from skeletal muscle. Biomaterials 2011, 32, 7870-7882. [CrossRef]

20. Burns, K.E.; Uhrig, R.F.; Jewett, M.E.; Bourbon, M.F.; Krupa, K.A. Characterizing the Role of Biologically Relevant Fluid Dynamics on Silver Nanoparticle Dependent Oxidative Stress in Adherent and Suspension In Vitro Models. Antioxidants 2021, 10, 832. [CrossRef]

21. Kestell, A.E.; DeLorey, G.T. Nanoparticles: Properties, Classification, Characterization, and Fabrication; Nova Science Publishers: New York, NY, USA, 2010.

22. Wahab, R.; Dwivedi, S.; Khan, F.; Mishra, Y.K.; Hwang, I.H.; Shin, H.S.; Musarrat, J.; Al-Khedhairy, A.A. Statistical analysis of gold nanoparticle-induced oxidative stress and apoptosis in myoblast (C2C12) cells. Colloids Surf. B Biointerfaces 2014, 123, 664-672. [CrossRef]

23. Seo, J.J.; Mandakhbayar, N.; Kang, M.S.; Yoon, J.-Y.; Lee, N.-H.; Ahn, J.; Lee, H.-H.; Lee, J.-H.; Kim, H.-W. Antibacterial, proangiogenic, and osteopromotive nanoglass paste coordinates regenerative process following bacterial infection in hard tissue. Biomaterials 2021, 268, 120593. [CrossRef] [PubMed]

24. Nelson, B.C.; Johnson, M.E.; Walker, M.L.; Riley, K.R.; Sims, C.M. Antioxidant cerium oxide nanoparticles in biology and medicine. Antioxidants 2016, 5, 15. [CrossRef]

25. Lee, N.H.; Kang, M.S.; Kim, T.H.; Yoon, D.S.; Mandakhbayar, N.; Jo, S.B.; Kim, H.S.; Knowles, J.C.; Lee, J.H.; Kim, H.W. Dual actions of osteoclastic-inhibition and osteogenic-stimulation through strontium-releasing bioactive nanoscale cement imply biomaterial-enabled osteoporosis therapy. Biomaterials 2021, 276, 121025. [CrossRef] [PubMed]

26. Lee, S.C.; Lee, N.H.; Patel, K.D.; Jang, T.S.; Knowles, J.C.; Kim, H.W.; Lee, H.H.; Lee, J.H. The Effect of Selenium Nanoparticles on the Osteogenic Differentiation of MC3T3-E1 Cells. Nanomaterials 2021, 11, 557. [CrossRef]

27. Daems, N.; Penninckx, S.; Nelissen, I.; Van Hoecke, K.; Cardinaels, T.; Baatout, S.; Michiels, C.; Lucas, S.; Aerts, A. Gold nanoparticles affect the antioxidant status in selected normal human cells. Int. J. Nanomed. 2019, 14, 4991. [CrossRef] 
28. Karahaliloglu, Z.; Kilicay, E. In vitro evaluation of bone cements impregnated with selenium nanoparticles stabilized by phosphatidylcholine (PC) for application in bone. J. Biomater. Appl. 2020, 35, 385-404. [CrossRef]

29. Vera, P.; Canellas, E.; Nerin, C. New Antioxidant Multilayer Packaging with Nanoselenium to Enhance the Shelf-Life of Market Food Products. Nanomaterials 2018, 8, 837. [CrossRef]

30. Zoidis, E.; Seremelis, I.; Kontopoulos, N.; Danezis, G.P. Selenium-Dependent Antioxidant Enzymes: Actions and Properties of Selenoproteins. Antioxidants 2018, 7, 66. [CrossRef] [PubMed]

31. Dorazilova, J.; Muchova, J.; Smerkova, K.; Kociova, S.; Divis, P.; Kopel, P.; Vesely, R.; Pavlinakova, V.; Adam, V.; Vojtova, L. Synergistic Effect of Chitosan and Selenium Nanoparticles on Biodegradation and Antibacterial Properties of Collagenous Scaffolds Designed for Infected Burn Wounds. Nanomaterials 2020, 10, 1971. [CrossRef] [PubMed]

32. Arteel, G.E.; Sies, H. The biochemistry of selenium and the glutathione system. Environ. Toxicol. Pharmacol. 2001, 10, 153-158. [CrossRef]

33. Sharma, P.; Jha, A.B.; Dubey, R.S.; Pessarakli, M. Reactive oxygen species, oxidative damage, and antioxidative defense mechanism in plants under stressful conditions. J. Bot. 2012, 2012, 217037. [CrossRef]

34. Stolzoff, M.; Webster, T.J. Reducing bone cancer cell functions using selenium nanocomposites. J. Biomed. Mater. Res. Part A 2016, 104, 476-482. [CrossRef]

35. Cardoso, B.R.; Roberts, B.R.; Bush, A.I.; Hare, D.J. Selenium, selenoproteins and neurodegenerative diseases. Metallomics 2015, 7, 1213-1228. [CrossRef]

36. Yuan, B.; Webster, T.J.; Roy, A.K. Cytoprotective effects of cerium and selenium nanoparticles on heat-shocked human dermal fibroblasts: An in vitro evaluation. Int. J. Nanomed. 2016, 11, 1427-1433. [CrossRef]

37. Schroterova, L.; Kralova, V.; Voracova, A.; Haskova, P.; Rudolf, E.; Cervinka, M. Antiproliferative effects of selenium compounds in colon cancer cells: Comparison of different cytotoxicity assays. Toxicol. Vitr. Int. J. Publ. Assoc. BIBRA 2009, 23, 1406-1411. [CrossRef]

38. Kieliszek, M.; Lipinski, B.; Blazejak, S. Application of Sodium Selenite in the Prevention and Treatment of Cancers. Cells 2017, 6, 39. [CrossRef] [PubMed]

39. Badr, D.M.; Hafez, H.F.; Agha, A.M.; Shouman, S.A. The Combination of $\alpha$-Tocopheryl Succinate and Sodium Selenite on Breast Cancer: A Merit or a Demerit? Oxidative Med. Cell. Longev. 2016, 2016, 4741694. [CrossRef]

40. Pang, K.L.; Chin, K.Y. Emerging Anticancer Potentials of Selenium on Osteosarcoma. Int. J. Mol. Sci. 2019, 20, 5318. [CrossRef]

41. Berggren, M.; Sittadjody, S.; Song, Z.; Samira, J.L.; Burd, R.; Meuillet, E.J. Sodium selenite increases the activity of the tumor suppressor protein, PTEN, in DU-145 prostate cancer cells. Nutr. Cancer 2009, 61, 322-331. [CrossRef]

42. Fatima, S.; Alfrayh, R.; Alrashed, M.; Alsobaie, S.; Ahmad, R.; Mahmood, A. Selenium Nanoparticles by Moderating Oxidative Stress Promote Differentiation of Mesenchymal Stem Cells to Osteoblasts. Int. J. Nanomed. 2021, 16, 331-343. [CrossRef]

43. Guo, L.; Xiao, J.; Liu, H.; Liu, H. Selenium nanoparticles alleviate hyperlipidemia and vascular injury in ApoE-deficient mice by regulating cholesterol metabolism and reducing oxidative stress. Metallomics 2020, 12, 204-217. [CrossRef]

44. Tugarova, A.V.; Mamchenkova, P.V.; Dyatlova, Y.A.; Kamnev, A.A. FTIR and Raman spectroscopic studies of selenium nanoparticles synthesised by the bacterium Azospirillum thiophilum. Spectrochim. Acta Part A Mol. Biomol. Spectrosc. 2018, 192, 458-463. [CrossRef] [PubMed]

45. Gunti, L.; Dass, R.S.; Kalagatur, N.K. Phytofabrication of Selenium Nanoparticles From Emblica officinalis Fruit Extract and Exploring Its Biopotential Applications: Antioxidant, Antimicrobial, and Biocompatibility. Front. Microbiol. 2019, $10,931$. [CrossRef]

46. Tapiero, H.; Townsend, D.; Tew, K. The antioxidant role of selenium and seleno-compounds. Biomed. Pharmacother. 2003, 57, 134-144. [CrossRef]

47. Tinggi, U. Selenium: Its role as antioxidant in human health. Environ. Health Prev. Med. 2008, 13, 102-108. [CrossRef]

48. Guo, L.; Huang, K.; Liu, H. Biocompatibility selenium nanoparticles with an intrinsic oxidase-like activity. J. Nanoparticle Res. 2016, 18, 74. [CrossRef]

49. Tang, J.; He, A.; Yan, H.; Jia, G.; Liu, G.; Chen, X.; Cai, J.; Tian, G.; Shang, H.; Zhao, H. Damage to the myogenic differentiation of C2C12 cells by heat stress is associated with up-regulation of several selenoproteins. Sci. Rep. 2018, 8, 10601. [CrossRef] [PubMed]

50. Poussard, S.; Decossas, M.; Le Bihan, O.; Mornet, S.; Naudin, G.; Lambert, O. Internalization and fate of silica nanoparticles in C2C12 skeletal muscle cells: Evidence of a beneficial effect on myoblast fusion. Int. J. Nanomed. 2015, 10, 1479-1492. [CrossRef]

51. Redza-Dutordoir, M.; Averill-Bates, D.A. Activation of apoptosis signalling pathways by reactive oxygen species. Biochim. Biphys. Acta 2016, 1863, 2977-2992. [CrossRef]

52. Park, I.S.; Mahapatra, C.; Park, J.S.; Dashnyam, K.; Kim, J.W.; Ahn, J.C.; Chung, P.S.; Yoon, D.S.; Mandakhbayar, N.; Singh, R.K.; et al. Revascularization and limb salvage following critical limb ischemia by nanoceria-induced Ref-1/APE1-dependent angiogenesis. Biomaterials 2020, 242, 119919. [CrossRef] [PubMed]

53. Sena, L.A.; Chandel, N.S. Physiological roles of mitochondrial reactive oxygen species. Mol. Cell 2012, 48, 158-167. [CrossRef]

54. Torres, S.; Campos, V.; León, C.; Rodríguez-Llamazares, S.; Rojas, S.; Gonzalez, M.; Smith, C.; Mondaca, M. Biosynthesis of selenium nanoparticles by Pantoea agglomerans and their antioxidant activity. J. Nanoparticle Res. 2012, 14, 1236. [CrossRef]

55. Bai, Y.; Qin, B.; Zhou, Y.; Wang, Y.; Wang, Z.; Zheng, W. Preparation and antioxidant capacity of element selenium nanoparticles sol-gel compounds. J. Nanosci. Nanotechnol. 2011, 11, 5012-5017. [CrossRef] [PubMed] 
56. Duran, B.O.S.; Goes, G.A.; Zanella, B.T.T.; Freire, P.P.; Valente, J.S.; Salomao, R.A.S.; Fernandes, A.; Mareco, E.A.; Carvalho, R.F.; Dal-Pai-Silva, M. Ascorbic acid stimulates the in vitro myoblast proliferation and migration of pacu (Piaractus mesopotamicus). Sci. Rep. 2019, 9, 2229. [CrossRef] [PubMed]

57. Liu, Y.; He, A.; Tang, J.; Shah, A.M.; Jia, G.; Liu, G.; Tian, G.; Chen, X.; Cai, J.; Kang, B.; et al. Selenium alleviates the negative effect of heat stress on myogenic differentiation of C2C12 cells with the response of selenogenome. J. Therm. Biol. 2021, 97, 102874. [CrossRef] [PubMed]

58. Thaloor, D.; Miller, K.J.; Gephart, J.; Mitchell, P.O.; Pavlath, G.K. Systemic administration of the NF-kappaB inhibitor curcumin stimulates muscle regeneration after traumatic injury. Am. J. Physiol. 1999, 277, C320-C329. [CrossRef] 